Atmos. Chem. Phys., 10, 9667-9680, 2010

www.atmos-chem-phys.net/10/9667/2010/

doi:10.5194/acp-10-9667-2010

(C) Author(s) 2010. CC Attribution 3.0 License.

\title{
Aircraft observations of enhancement and depletion of black carbon mass in the springtime Arctic
}

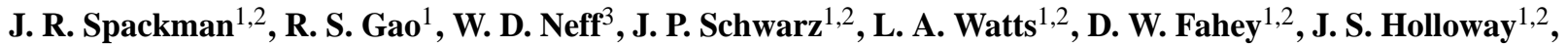 \\ T. B. Ryerson ${ }^{1}$, J. Peischl ${ }^{1,2}$, and C. A. Brock ${ }^{1}$ \\ ${ }^{1}$ National Oceanic and Atmospheric Administration, Earth System Research Laboratory, Chemical Sciences Division, \\ Boulder, Colorado, USA \\ ${ }^{2}$ Cooperative Institute for Research in Environmental Sciences, University of Colorado, Boulder, Colorado, USA \\ ${ }^{3}$ National Oceanic and Atmospheric Administration, Earth System Research Laboratory, Physical Sciences Division, \\ Boulder, Colorado, USA
}

Received: 29 May 2010 - Published in Atmos. Chem. Phys. Discuss.: 21 June 2010

Revised: 24 September 2010 - Accepted: 27 September 2010 - Published: 12 October 2010

\begin{abstract}
Understanding the processes controlling black carbon $(\mathrm{BC})$ in the Arctic is crucial for evaluating the impact of anthropogenic and natural sources of BC on Arctic climate. Vertical profiles of $\mathrm{BC}$ mass loadings were observed from the surface to near 7-km altitude in April 2008 using a Single-Particle Soot Photometer (SP2) during flights on the NOAA WP-3D research aircraft from Fairbanks, Alaska. These measurements were conducted during the NOAAsponsored Aerosol, Radiation, and Cloud Processes affecting Arctic Climate (ARCPAC) project. In the free troposphere, the Arctic air mass was influenced by long-range transport from biomass-burning and anthropogenic source regions at lower latitudes especially during the latter part of the campaign. Average $\mathrm{BC}$ mass mixing ratios peaked at about $150 \mathrm{ng}$ BC (kg dry air $)^{-1}$ near $5.5 \mathrm{~km}$ altitude in the aged Arctic air mass and $250 \mathrm{ng} \mathrm{kg}^{-1}$ at $4.5 \mathrm{~km}$ in biomassburning influenced air. BC mass loadings were enhanced by up to a factor of 5 in biomass-burning influenced air compared to the aged Arctic air mass. At the bottom of some of the profiles, positive vertical gradients in $\mathrm{BC}$ were observed over the sea-ice. The vertical profiles generally occurred in the vicinity of open leads in the sea-ice. In the aged Arctic
\end{abstract}

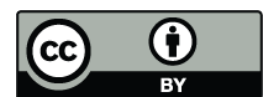

Correspondence to: J. R. Spackman (ryan.spackman@noaa.gov) air mass, BC mass loadings more than doubled with increasing altitude within the ABL and across the boundary layer transition while carbon monoxide $(\mathrm{CO})$ remained constant. This is evidence for depletion of BC mass in the ABL. BC mass loadings were positively correlated with $\mathrm{O}_{3}$ in ozone depletion events (ODEs) for all the observations in the ABL. Since bromine catalytically destroys ozone in the ABL after being released as molecular bromine in regions of new seaice formation at the surface, the $\mathrm{BC}-\mathrm{O}_{3}$ correlation suggests that $\mathrm{BC}$ particles were removed by a surface process such as dry deposition. We develop a box model to estimate the dry deposition flux of $\mathrm{BC}$ mass to the snow constrained by the vertical profiles of $\mathrm{BC}$ mass in the ABL. Open leads in the sea-ice may increase vertical mixing and entrainment of pollution from the free troposphere possibly enhancing the deposition of $\mathrm{BC}$ aerosol to the snow.

\section{Introduction}

Black carbon (BC) in the Arctic directly contributes to regional climate change through radiative heating of the atmosphere and warming at the snow surface due to absorption of incoming solar shortwave radiation (Shindell and Faluvegi, 2009; McConnell et al., 2007; Hansen and Nazarenko, 2004). Despite the dimming caused by the absorption of

Published by Copernicus Publications on behalf of the European Geosciences Union. 
solar radiation by $\mathrm{BC}$ aerosol aloft, $\mathrm{BC}$ deposited in snow has been shown to exacerbate Arctic warming through the snow albedo effect, a process whereby surface warming causes snow and ice removal leading to a decrease in the surface albedo that triggers additional warming (Flanner et al., 2007, 2009). The fourth assessment of the Intergovernmental Panel on Climate Change (IPCC) reported that BC in snow accounts for a forcing of $0.1 \mathrm{~W} \mathrm{~m}^{-2}$ with a factor of two in uncertainty (IPCC, 2007). Measurements of BC aerosol in the Arctic troposphere are both limited and needed to constrain transport and microphysics in global aerosol models, evaluate climate impacts, and develop mitigation strategies (Koch et al., 2009; Shindell et al., 2008).

Enhancements of BC and other tracers of pollution have been observed for decades in the Arctic troposphere in the winter and early spring (Sturges, 1991; Hansen and Novakov, 1989; Sharma et al., 2006; Law and Stohl, 2007; Koch et al., 2009). These enhancements emerge from the chemistry and dynamics unique to high latitudes at this time of year. In the winter and early spring, the colder temperatures and weaker solar insolation lead to stratification in the Arctic troposphere that inhibits precipitating cloud formation and, hence, the wet removal of aerosols. The weaker insolation and colder temperatures also slow down the photochemistry and reaction rates that govern the chemical tracer abundances. As a result, aerosols and tracers are generally longer lived in the Arctic in winter and early spring than at other times of the year.

Most of the $\mathrm{BC}$ aerosol in the Arctic troposphere is produced from incomplete fossil-fuel and biomass-burning combustion processes at lower latitudes and transported into the Arctic along isentropic surfaces (Stohl, 2006). Some modeling studies suggest anthropogenic sources from Europe and Asia maintain the enhanced level of pollution at northern high latitudes often referred to as Arctic haze (Quinn et al., 2007; Koch and Hansen, 2005). A number of other works have shown how transport of biomass-burning plumes from agricultural and forest fires at midlatitudes contribute to Arctic haze particularly in spring (Saha et al., 2010; Warneke et al., 2009; Generoso et al., 2007). The partitioning of anthropogenic and biomass-burning influenced air masses in the springtime Arctic largely depends on interannual variability in biomass burning at northern midlatitudes (Warneke et al., 2010).

$\mathrm{BC}$ mass is observed in snow at sites throughout northern high latitudes (Hegg et al., 2010, 2009; Doherty et al., 2010). The seasonally enhanced BC mass loadings in the Arctic troposphere may lead to increased wet and dry deposition of $\mathrm{BC}$ aerosol to the snow or ice through precipitation scavenging and direct contact with the snow or ice surface, respectively. The mixing state of BC (e.g., Schwarz et al., 2008; Shiraiwa et al., 2007; Jacobson, 2001) may be an important aspect in the wet removal of BC particles because they are aged and mixed with hydrophilic materials such as sulfate in the Arctic (McNaughton et al., 2010). However, dry removal may play a more important role than wet removal in depositing $\mathrm{BC}$ particles to the snow because of limited precipitation scavenging in the Arctic in winter and spring (Brock et al., 2010). Atmospheric perturbations that facilitate the mixing of $\mathrm{BC}$ from the free troposphere into the Arctic boundary layer (ABL), such as through open leads (Serreze et al., 1992; Andreas and Murphy, 1986) or enhanced vertical wind shear, might lead to increased dry deposition of BC aerosol to the snow (Strunin et al., 1997).

Here we present vertical profiles of $\mathrm{BC}$ mass in the troposphere in the springtime Arctic using data from a SingleParticle Soot Photometer (SP2) to measure the refractory mass of individual $\mathrm{BC}$ particles. We first show enhancements of $\mathrm{BC}$ mass in the free troposphere in biomass-burning plumes relative to the aged Arctic air mass and then focus on the observed depletions of BC mass in the ABL over the sea-ice and open leads north of Alaska. We present the correlations between simultaneous measurements of $\mathrm{BC}$ mass, carbon monoxide $(\mathrm{CO})$ and ozone $\left(\mathrm{O}_{3}\right)$ in the ABL to examine the processes controlling the removal of BC. Lastly, we use a simple box model constrained by the observed vertical profiles of $\mathrm{BC}$ to bound the flux of $\mathrm{BC}$ from the free troposphere to the snow or ice surface.

\section{Aircraft measurements}

The NOAA WP-3D research aircraft was deployed to Fairbanks, Alaska $\left(65^{\circ} \mathrm{N}, 148^{\circ} \mathrm{W}\right)$ in April 2008 for the Aerosol, Radiation, and Cloud Processes affecting Arctic Climate (ARCPAC) campaign (Brock et al., 2010). ARCPAC occurred during POLARCAT as part of the International Polar Year (IPY) research activities in the Arctic. POLARCAT is the Polar Study using Aircraft, Remote Sensing, Surface Measurement and Models, of Climate, Chemistry, Aerosols, and Transport. We present measurements of $\mathrm{BC}$ mass loadings, $\mathrm{CO}, \mathrm{O}_{3}$, and meteorological parameters from 5 flights in the Arctic, 12-21 April 2008, spanning 0.1-7.4 km in altitude, $65-75^{\circ} \mathrm{N}$ in latitude, and $126-165^{\circ} \mathrm{W}$ in longitude (Fig. 1). All of the flights were 7.5 to $9 \mathrm{~h}$ in duration and occurred during daylight hours. The aircraft probed the ABL mostly over the ice and open leads north of Alaska for a total $\sim 7 \mathrm{~h}$ in duration. The ABL is defined in this work as the surface layer, typically characterized by a temperature inversion, over the sea-ice and open leads up to about $300 \mathrm{~m}$ altitude based on the temperature profiles from the WP-3D. This layer generally appears consistent in depth and inversion strength with temperature soundings over the pack ice in the central Arctic north of Alaska (Tjernström and Graversen, 2009). The free troposphere refers to the region immediately above the ABL.

The SP2 measures the refractory $\mathrm{BC}$ mass in individual $\mathrm{BC}$-containing particles using laser-induced incandescence, whereby the $\mathrm{BC}$ fraction is heated to its boiling point and the thermal radiation, or incandescence, emitted by the intensely 


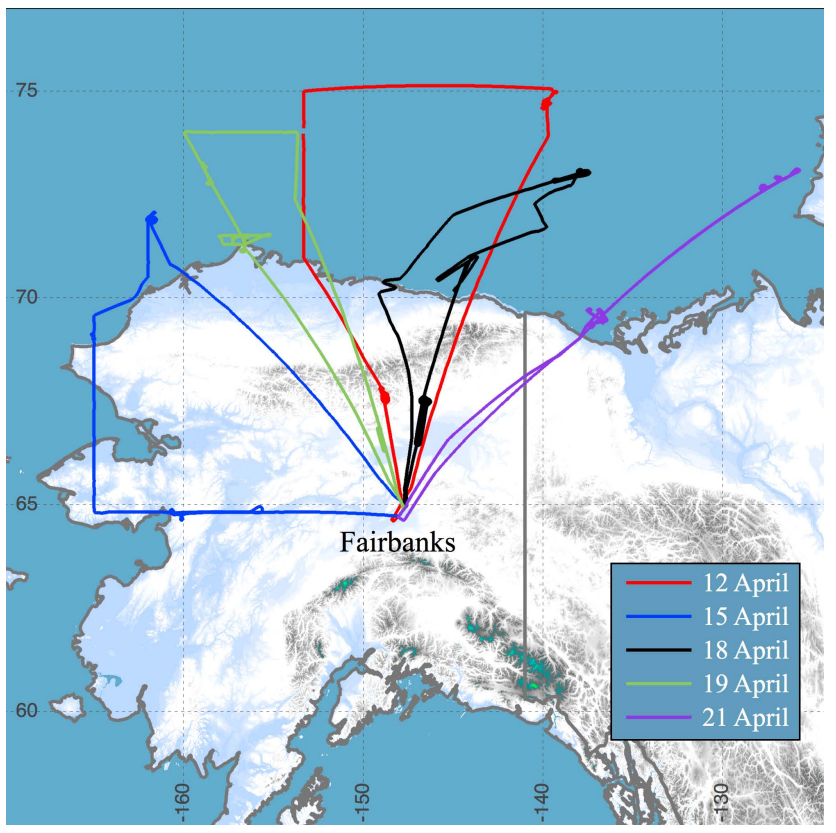

Fig. 1. The ARCPAC flight tracks for the data presented in this work (image courtesy of K. Aikin). The campaign was based from Fairbanks, Alaska $\left(65^{\circ} \mathrm{N}, 148^{\circ} \mathrm{W}\right)$.

hot material is detected (Schwarz et al., 2006). The measurement of refractory mass is continuous, $\mathrm{BC}$-specific, proportional to the incandescence signal, and independent of particle mixing state and morphology (Slowik et al., 2007). BC mass loading is reported as a mass mixing ratio in $\mathrm{ng} B \mathrm{BC}$ $(\mathrm{kg} \text { dry air })^{-1}$. For the data presented here, the SP2 detected $\mathrm{BC}$ core sizes in the range of 0.090 to $0.600 \mu \mathrm{m}$ volumeequivalent diameter (VED), based on a void-free density of $2 \mathrm{~g} \mathrm{~cm}^{-3}$ for ambient $\mathrm{BC}$ aerosol. This assumed density does not affect any results in this work except the VED in the constructed size distributions. This size range includes $\sim 90 \%$ of the $\mathrm{BC}$ mass and $\sim 50 \%$ of the number of $\mathrm{BC}$ particles assuming a lognormal distribution of $\mathrm{BC}$ mass in the fine mode peaked near $0.200 \mu \mathrm{m}$ (Schwarz et al., 2006). The measured $\mathrm{BC}$ mass mixing ratios reported in this work have been multiplied by 1.1 to account for the unmeasured mass outside the SP2 detection range. However, this may introduce a small error $(<10 \%)$ to the reported $\mathrm{BC}$ mass mixing ratios due to variability in the mode of the size distributions. Flight data from the PALMS instrument, a single-particle laser mass spectrometer, indicating cloud contamination of its aerosol inlet (Froyd et al., 2010) were used to remove the SP2 data acquired in clouds. The uncertainty of the reported BC mass loadings during ARCPAC is approximately $40 \%$ attributed primarily to uncertainty in $\mathrm{BC}$ mass calibration with a lesser contribution from sample flow uncertainty.
The SP2 sampled ambient aerosol behind a $1 \mu \mathrm{m}$ particle impactor through a low-turbulence inlet (LTI) (Brock et al., 2004; Wilson et al., 2004). The sampling inlet was designed and mounted to the aircraft in a manner to sample the ambient air stream without contamination from the boundary layer along the skin of the aircraft. To ensure no particle losses during sampling, an intercomparison was performed between aerosol instruments sampling off the LTI. For various test aerosols introduced, good agreement between the instruments at their different sampling points along the sample line indicated minimal aerosol losses during transport along the sample tubing.

In situ measurements of $\mathrm{CO}$ were acquired at $1 \mathrm{~Hz}$ by a vacuum ultraviolet resonance fluorescence instrument with an uncertainty of $\pm 5 \%$ (Holloway et al., 2000). $\mathrm{O}_{3}$ was measured with a NO-induced chemiluminescence technique with an estimated uncertainty of $\pm(0.05 \mathrm{ppb}+4 \%)$ for the $1-\mathrm{Hz}$ data (Ryerson et al., 1998).

\section{Observations of $\mathrm{BC}$ mass loadings in the Arctic troposphere}

Airborne BC measurements in the Arctic troposphere were limited prior to the POLARCAT campaigns in 2008 and consisted mostly of filter-based absorption techniques sampling bulk aerosol (Hansen and Rosen, 1984; Hansen and Novakov, 1989). In addition to the measurements presented in this work, two other SP2 instruments aboard the NASA DC-8 and P3-B research aircraft collected single-particle BC data in spring 2008 during the NASA-sponsored Arctic Research of the Composition of the Troposphere from Aircraft and Satellites (ARCTAS) campaign (Jacob et al., 2010). The NASA aircraft sampled biomass-burning plumes less frequently than the NOAA WP-3D. Also, the NOAA WP-3D probed the ABL around open leads north of Alaska for a longer time than either NASA aircraft that sampled a larger geographical area of the Arctic. The SP2 measurements of $\mathrm{BC}$ mass loadings generally agreed to within stated uncertainties during wingtip-to-wingtip intercomparisons between the NOAA and NASA aircraft (G. Chen, private communication, 2009). The Arctic vertical profiles from all the SP2 measurements are shown in the context of a measurementmodel intercomparison in Fig. 10 of Koch et al. (2009).

\subsection{Enhancement of $\mathrm{BC}$ mass in the free troposphere}

The observed vertical profiles of BC mass loadings from 5 flights in the Arctic are shown in Fig. 2. The data points are $30 \mathrm{~s}$ averages with a horizontal spatial resolution of $3 \mathrm{~km}$. The data in blue were collected on the 12 April 2008 flight in the aged Arctic air mass and the data in red were acquired on 4 flights (15-21 April) in air strongly influenced by long-range biomass-burning plumes. For simplicity, we classify the air mass types by flight date since a 


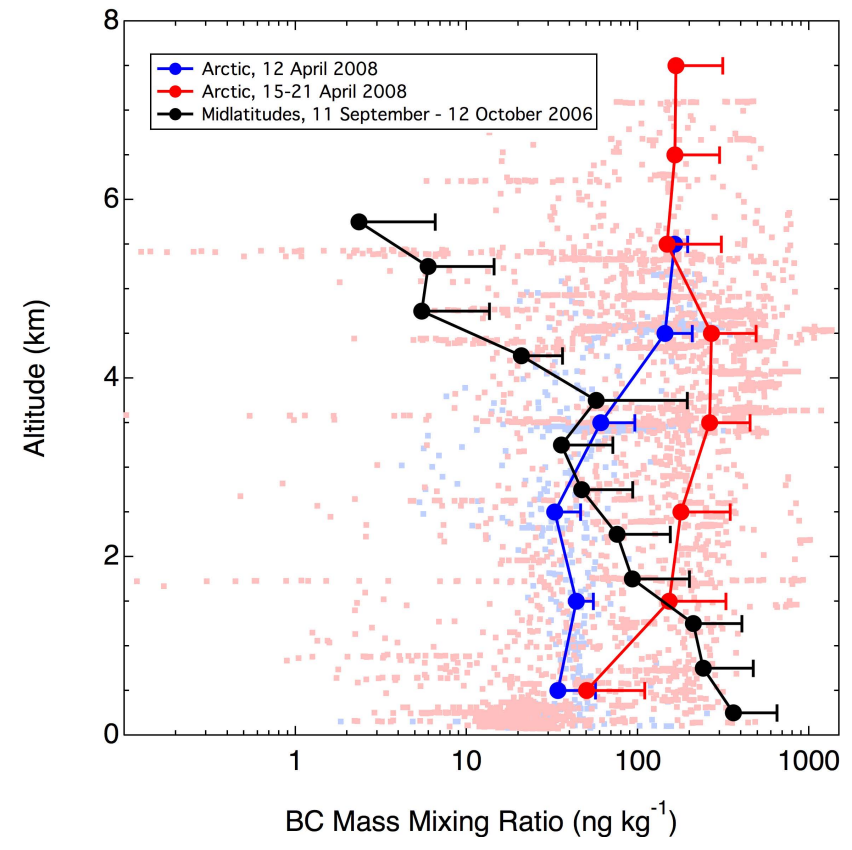

Fig. 2. Vertical profiles of $\mathrm{BC}$ mass mixing ratio for 5 flights in the Arctic during ARCPAC and 16 flights at midlatitudes in eastern Texas during the Texas Air Quality Study. The data in blue and red are from 1 flight in the aged Arctic air mass and 4 flights in long-range biomass-burning plumes, respectively. The small dots and line markers denote $30 \mathrm{~s}$ averages and $1 \mathrm{~km}$ mean values, respectively, of BC mass mixing ratio, except for the midlatitude data where $0.5 \mathrm{~km}$ averages are shown without the underlying $30 \mathrm{~s}$ data. The horizontal bars represent one standard deviation on both sides of the mean but are only drawn on the positive side for visual clarity.

quantitative distinction is not important to the results in this work. We use the phrase, aged Arctic air, in a qualitative sense to exclude fresh pollution from sources inside and outside the Arctic, such as biomass-burning plumes. The free tropospheric region sampled by the NOAA WP-3D aircraft was frequently influenced by long-range biomass-burning plumes from southern Russia and southeast Siberia during ARCPAC after the 12 April flight (Warneke et al., 2009). Although the 15-21 April flights were influenced by biomassburning, it is important to note the air sampled includes a mixture of biomass-burning plumes and aged Arctic air.

For both types of air masses, the mean $\mathrm{BC}$ mass loadings increase with altitude in the springtime Arctic. Average BC mass mixing ratios peak at about $150 \mathrm{ng} \mathrm{kg}^{-1}$ near $5.5 \mathrm{~km}$ altitude in the aged Arctic air mass and over $250 \mathrm{ng} \mathrm{kg}^{-1}$ in biomass-burning influenced air at $4.5 \mathrm{~km}$. BC mass loadings are enhanced by up to a factor of 5 in biomass-burning influenced air compared to the aged Arctic air mass. The BC mass loadings in the middle troposphere are comparable to those observed in the planetary boundary layer in a polluted urban environment in the United States (Spackman et al., 2008). It is worth noting here that global aerosol models generally underestimate advection of $\mathrm{BC}$ or overestimate removal of
BC during transport to the Arctic (Koch et al., 2009). When placed in a representative context, these important observations can be used to apply bounds to physical processes in models.

The profiles obtained with the SP2 during ARCPAC generally show lower $\mathrm{BC}$ mass loadings compared to those from an aethalometer during the Arctic Gas and Aerosol Sampling Program (AGASP) conducted in the Alaskan Arctic (Schnell, 1984). Agreement between the AGASP and ARCPAC data should not necessarily be expected because of variability in long-range transport and changes in $\mathrm{BC}$ emissions over time. The ARCPAC profiles show distinct enhancements in $\mathrm{BC}$ mass in the middle and upper troposphere compared to the lower troposphere unlike the composite profiles from AGASP-I (March 1983) and -II (April 1986) that indicate a polluted lower troposphere and decreasing BC mass loadings with increasing altitude. In summary, BC mass mixing ratios decreased from approximately 150 $400 \mathrm{ng} \mathrm{kg}^{-1}$ at lower altitudes to $20-75 \mathrm{ng} \mathrm{kg}^{-1}$ at $8-10 \mathrm{~km}$ (Hansen and Novakov, 1989).

The ARCPAC profiles contrast with profiles at midlatitudes (Spackman et al., 2008) and in the tropics (not shown) (Schwarz et al., 2008) where BC mass generally decreases by 2 to 3 orders of magnitude from the surface to $5 \mathrm{~km}$ altitude, given by the black line in Fig. 2. These profiles may still be consistent because the tropics and midlatitudes are linked to high latitudes by meridional exchange along isentropic surfaces (Stohl, 2006; Quinn et al., 2007). Since an air parcel is lofted in altitude as it is advected poleward, pollution in the lower troposphere at midlatitudes maps to the middle troposphere at high latitudes in the absence of diabatic processes during transport.

\subsection{Depletion of $\mathrm{BC}$ mass in the $\mathrm{ABL}$}

Vertical profiles of BC mass and $\mathrm{CO}$ are shown in detail in Fig. 3 for the lowest $2 \mathrm{~km}$ of the flight tracks displayed in Fig. 1. Each flight includes one ascent profile from and one descent profile into Fairbanks with local pollution influence, marked by the red points, with the normally observed decrease in BC mass with increasing altitude above a polluted boundary layer. The profiles denoted by the blue points are mostly north of Alaska over the ice and open leads. A large positive but variable vertical gradient in $\mathrm{BC}$ mass was observed in the lowest few hundred meters over the ice and open leads on several of the flights. BC mass mixing ratios increase by up to a factor of 6 from the minimum altitude of the WP-3D in the ABL up to $750 \mathrm{~m}$ in the free troposphere, observed on 12, 18, 21 April. Figure 3 is a composite of all the vertical profiles of $\mathrm{BC}$ and $\mathrm{CO}$ and offers some indication of the persistence of the $\mathrm{BC}$ vertical gradient during multiple profiles. These data include both spiral and slantwise flight profiles; the latter profiles may add horizontal variability to the results. While the WP-3D aircraft extensively sampled the ABL, there are limited profile data 


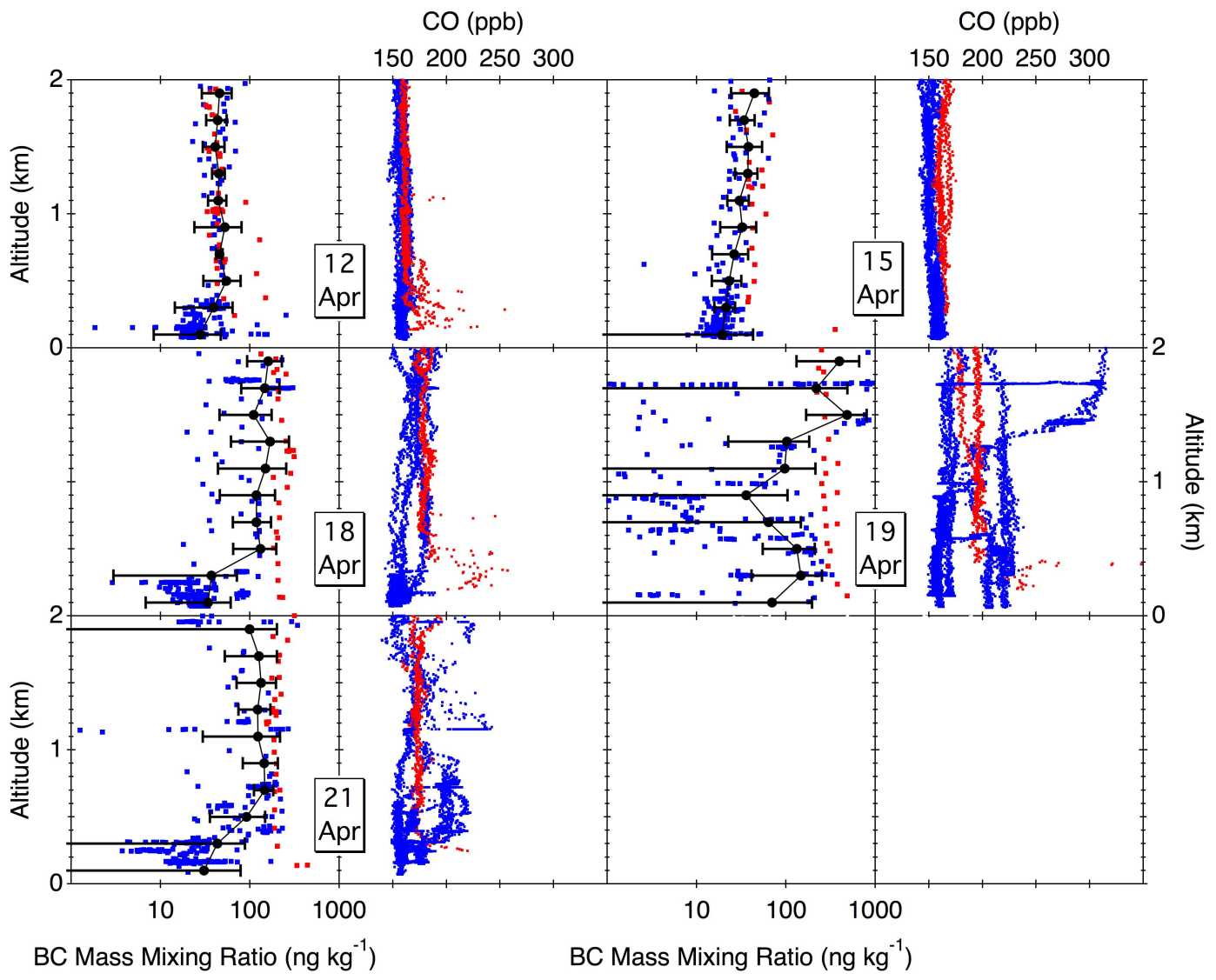

Fig. 3. Vertical profiles of $\mathrm{BC}$ mass loadings and $\mathrm{CO}$ in the lowest $2 \mathrm{~km}$ altitude for all the flights during ARCPAC. The $\mathrm{BC}$ and $\mathrm{CO}$ data points are $30 \mathrm{~s}$ and $1 \mathrm{~s}$ data, respectively. The blue points denote $\mathrm{BC}$ data over the ice and open leads north of Alaska and the red points correspond to ascent/descent data at Fairbanks. The black lines with bars represent the mean BC profiles including the Fairbanks data with one standard deviation around the mean in each $200 \mathrm{~m}$ altitude bin.

between this layer and the free troposphere with widely varying aerosol and chemical compositions during the sampling periods especially $18-21$ April.

Since BC aerosol and CO are both byproducts of incomplete combustion, they are often well correlated in the troposphere (e.g., Spackman et al., 2008). In the springtime Arctic, background values of $\mathrm{CO}$ are $\sim 160 \mathrm{ppb}$ (Brock et al., 2010). As shown in Fig. 3 on the 12 April flight in the aged Arctic air mass, background values of $\mathrm{CO}$ persisted throughout the lowest $2 \mathrm{~km}$ while $\mathrm{BC}$ mass increased by a factor of 2 to 3 from 100 to $500 \mathrm{~m}$ altitude. The observed gradient in $\mathrm{BC}$ with respect to constant values of $\mathrm{CO}$ indicates that the lower $\mathrm{BC}$ mass loadings in the $\mathrm{ABL}$ cannot be explained by air mass advection in which a cleaner air mass with less BC and $\mathrm{CO}$ was mixed into the $\mathrm{ABL}$ from the free troposphere at an earlier time. Rather, the simultaneous measurements are consistent with the physical removal of $\mathrm{BC}$ aerosol from this air mass through deposition. Size distributions of BC mass in the ABL and free troposphere on 12 April support this conclusion (Fig. 4). The modes for both of the mass distributions are $\sim 0.160 \mu \mathrm{m}$ and the geometric standard deviations are nearly identical, suggesting the air masses in the
$\mathrm{ABL}$ and the free troposphere have similar sources. The data from two other aerosol instruments (for details of the NMASS and UHSAS instruments, see Brock et al., 2004) aboard the WP-3D aircraft that measure particle number and size distributions also showed evidence for particle removal in the ultrafine and fine modes (i.e., $0.004-1 \mu \mathrm{m}$ ). On the whole, the tracer and aerosol data across the boundary layer transition strongly suggest the air masses in the ABL and free troposphere are from the same sources. For comparison, the SP2 instruments on the NASA DC- 8 and P-3B reported very limited $\mathrm{BC}$ mass depletion compared to that observed on the NOAA WP-3D. The processes controlling BC aerosol in the $\mathrm{ABL}$ will be explored in greater detail using $\mathrm{BC}-\mathrm{CO}$ and $\mathrm{O}_{3}-\mathrm{BC}$ correlations in Sect. 4.

Polluted midlatitude air was advected into the Alaskan Arctic and was sampled from 15 April through the remainder of the campaign (Brock et al., 2010; Fuelberg et al., 2010). An analysis using chemical signatures and FLEXPART, a Lagrangian particle dispersion model, attributes most of the pollution to agricultural and forest fires in Kazakhstan and the Lake Baikal region of Siberia, respectively (Warneke et al., 2009). Most of these plumes were observed above 


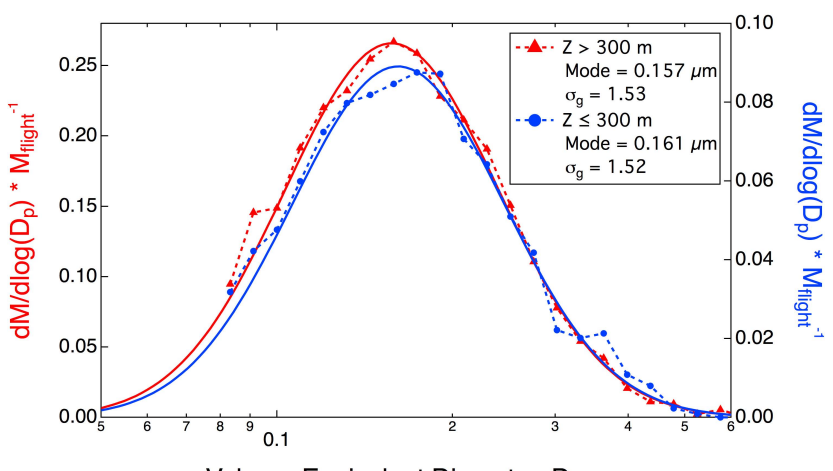

Volume-Equivalent Diameter, $D_{p}(\mu \mathrm{m})$

Fig. 4. Mass size distributions for $\mathrm{BC}$ aerosol in the $\mathrm{ABL}$ (blue) and free troposphere (red) on 12 April 2008. The free tropospheric data include the full altitude profiles immediately before (84698-86798 s, UTC) and after (87827-89447 s) the ABL flight segment (86799-87826 s). The flight context for these distributions can be seen more clearly from the time series in Fig. 5. The free tropospheric segments bracket the ABL profiles in Fig. 6B. The size distributions have been normalized by the total measured $\mathrm{BC}$ mass for the flight $\left(\mathrm{M}_{\text {flight }}\right)$. The modes and geometric standard deviations $\left(\sigma_{g}\right)$ are reported for the lognormal fits (solid lines) to the data.

$2 \mathrm{~km}$ altitude. In fact, less than $1 \%$ of the data from air sampled in the ABL during ARCPAC are characterized by $\mathrm{CO}$ values greater than $200 \mathrm{ppb}$, a value typical of biomassburning plumes sampled in the free troposphere. These few data were observed on 19 April near the surface at Barrow, Alaska. Ozonesonde data from the NOAA Global Monitoring Division (GMD) baseline site at Barrow on this date indicated biomass-burning plumes were advected to the surface (S. J. Oltmans, private communication, 2009) consistent with the $\mathrm{BC}$ and $\mathrm{CO}$ data in Fig. 3. With this one exception, the plumes in the free troposphere were decoupled from the $\mathrm{ABL}$ on the timescales of several days during which these measurements were taken.

BC mass mixing ratios increased by about a factor of 6 with increasing altitude in the ABL and across the boundary layer transition up to $750 \mathrm{~m}$ in the free troposphere on 18 and 21 April. Enhanced CO values of 180 to $220 \mathrm{ppb}$ at the top of the ABL during this period indicate the prevalence of biomass-burning plumes in the free troposphere and suggest the $\mathrm{BC}$ gradient is attributable to both advection and depletion. To avoid the complication from the advection of biomass-burning layers aloft, we quantify the $\mathrm{BC}$ removal based only on data from 12 April, in the aged Arctic air mass before the biomass-burning plumes reached the Arctic. The time series of altitude, latitude, $\mathrm{O}_{3}, \mathrm{CO}, \mathrm{BC}$ mass, and seasurface temperature (SST) for the 12 April flight are shown in Fig. 5. Sea-surface temperature is a remote sensing measurement of the temperature at the sea-ice or open water surface and is most meaningful when the aircraft is a couple kilometers or less above the surface. The spikes in the SST data

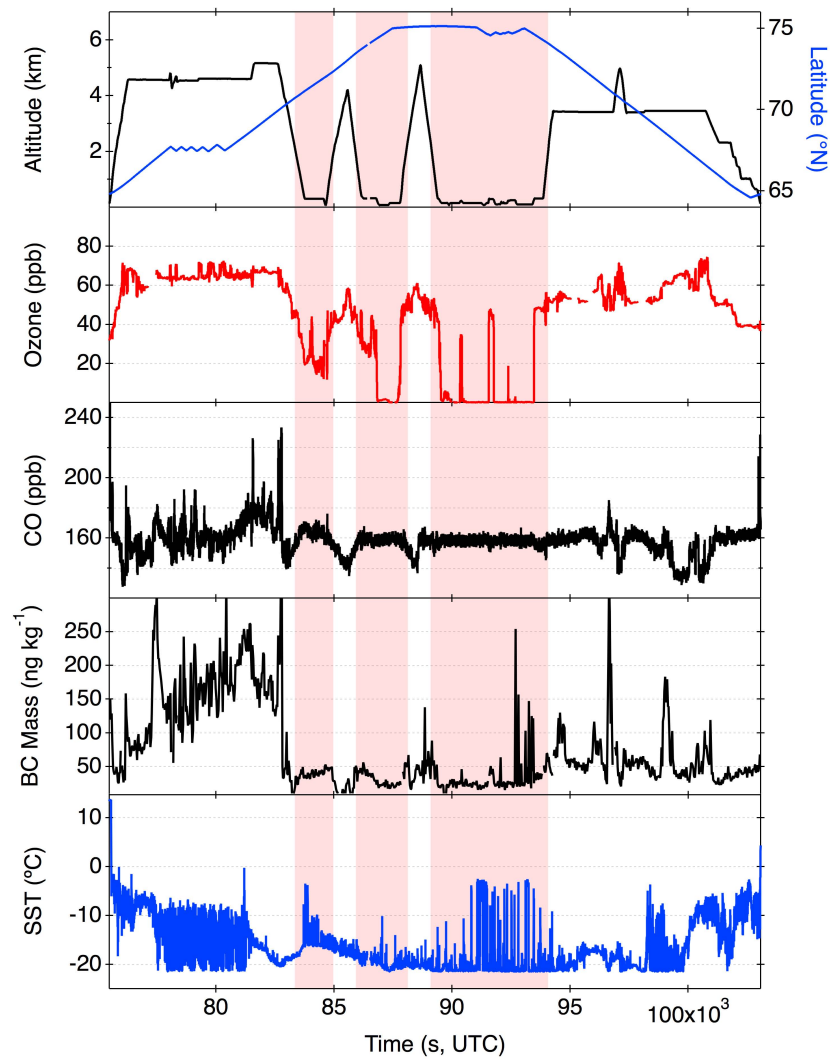

Fig. 5. Time series of altitude, latitude, ozone, CO, BC mass, and SST for the flight of 12 April 2008. The shaded segments highlight the parts of the flight where the NOAA WP-3D aircraft profiled the lowest $2 \mathrm{~km}$ altitude over the sea-ice and open leads.

in the shaded regions of Fig. 5 indicate the aircraft is flying repeatedly over the sea-ice and open leads. We include $\mathrm{O}_{3}$ data here because $\mathrm{O}_{3}$ is typically depleted in the ABL over the snow and ice due to bromine-catalyzed $\mathrm{O}_{3}$ destruction (Simpson et al., 2007) coincident with the observations of $\mathrm{BC}$ removal. Note the nearly complete removal of $\mathrm{O}_{3}$ in the second and third segments. This correlation will be discussed in more detail in the next section in the context of the $\mathrm{BC}$ mass depletions.

Low-altitude profile segments for the shaded regions in Fig. 5 are shown in Fig. 6 for $\mathrm{BC}, \mathrm{CO}, \mathrm{O}_{3}$, and potential temperature. The shaded region in Fig. 6 marks the ABL and the top of this layer is defined as the lowest altitude point above the surface where the vertical derivative of the potential temperature begins to increase which is often coincident with a weak low-level jet, generally at $\sim 300 \mathrm{~m}$ altitude. In both Fig. $6 \mathrm{~b}$ and c, there are positive vertical gradients in $\mathrm{BC}$ mass loadings in the ABL which are well correlated with ozone depletions and generally occur in the vicinity of open leads in the sea-ice. As mentioned earlier, this gradient occurs while $\mathrm{CO}$ is unvarying. In Fig. 6b, the spiral ascent (red) and slantwise descent data (blue) are shown separately because of the 


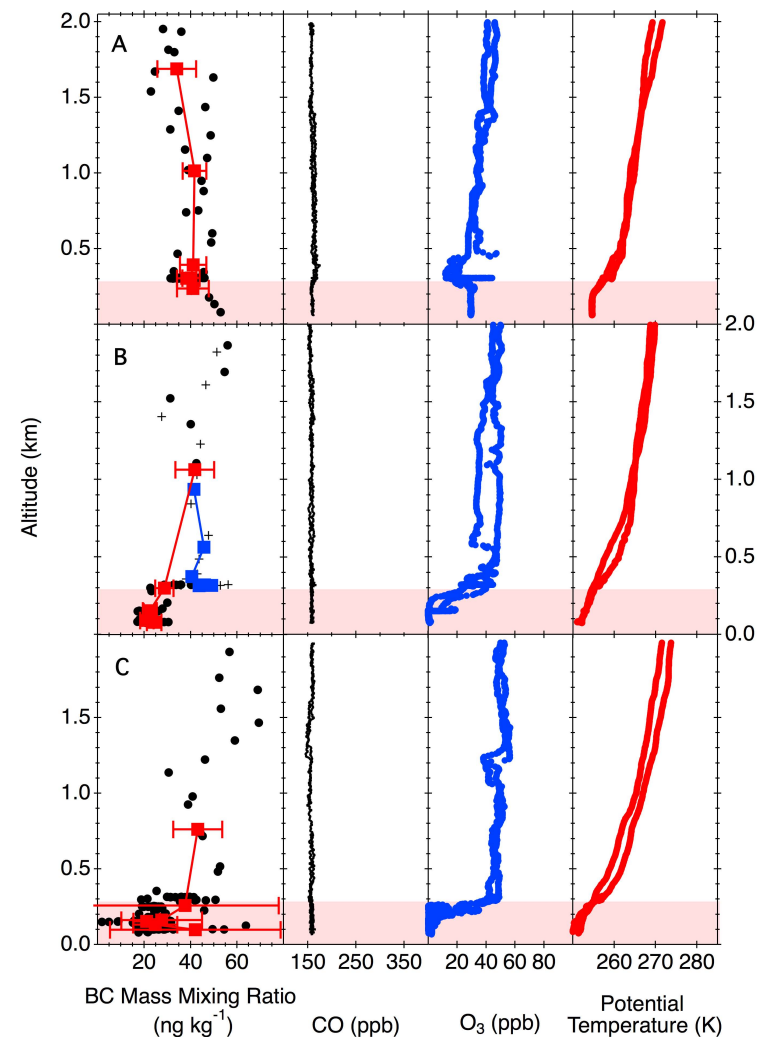

Fig. 6. Vertical profiles of $\mathrm{BC}$ mass, $\mathrm{CO}, \mathrm{O}_{3}$, and potential temperature for the boundary layer flight segments on 12 April 2008 highlighted in Fig. 5. The shaded regions mark the ABL. The profiles of $\mathrm{BC}$ mass consist of mean values of $\mathrm{BC}$ mass binned by altitude where each bin represents an equal fraction of the data. In (B), the ascent (red line, circles) and descent data (blue line, plus markers) are segregated. The $\mathrm{BC}$ profiles consist of $30 \mathrm{~s}$ data and the $\mathrm{CO}, \mathrm{O}_{3}$, and potential temperature profiles are $1 \mathrm{~s}$ data.

variability in the free troposphere over the geographical area of the profiles. In Fig. 6a, the limited BC data in the ABL prevent any conclusions from these particular profiles. We use an average of the ascent and descent profiles in Fig. 6b (shown in Fig. 11) to estimate the difference in BC mixing ratio of $\sim 20 \mathrm{ng} \mathrm{kg}^{-1}$ between the top of the boundary layer and $75 \mathrm{~m}$ altitude, at the bottom of the profile. The mean profile from Fig. $6 \mathrm{~b}$ is used to estimate the $\mathrm{BC}$ depletion because the $\mathrm{BC}$ variability is relatively small compared to other profiles such as in Fig. 6c. We assume the $20 \mathrm{ng} \mathrm{kg}^{-1} \mathrm{BC}$ difference from the profile in Fig. $6 \mathrm{~b}$ extends $300 \mathrm{~m}$ over the full depth of the ABL to calculate a deposition flux of $\mathrm{BC}$ to the snow in Sect. 4.

\section{BC deposition}

The processes controlling $\mathrm{BC}$ aerosol in the $\mathrm{ABL}$ include long-range transport and deposition. Since there are limited local anthropogenic sources and it is too early for biomass- burning in the springtime Arctic, most of the $\mathrm{BC}$ reaches the Arctic troposphere from lower latitudes by advection in the free troposphere. Then, it may be slowly mixed into the $\mathrm{ABL}$ or more rapidly entrained by episodic events during advection over open leads. Loss processes for BC aerosol include wet and dry deposition. Wet deposition might occur in a saturated layer in the ABL or in cloud layers in the free troposphere while dry deposition occurs by $\mathrm{BC}$ particles coming in direct contact with snow or ice through mechanical mixing in the ABL.

Open leads emit heat and moisture to the Arctic atmosphere and both may influence BC removal in the ABL. Open leads perturb the stable $\mathrm{ABL}$ because the temperature difference between the pack ice and the open water induces convection over and downstream of the lead (Anderson and Neff, 2008; Serreze et al., 1992; Andreas and Murphy, 1986). Another aircraft study in the Arctic troposphere has shown up to one-third removal of total aerosol in the ABL attributed to increased turbulent diffusion associated with open leads in the sea-ice (Strunin et al., 1997). Open leads may enhance (i) mixing in the $\mathrm{ABL}$ facilitating the deposition of $\mathrm{BC}$ to the snow or ice and (ii) entrainment of air from the free troposphere which is often polluted in the springtime Arctic due to long-range transport. However, the ARCPAC dataset shows no evidence for (ii), at least for the limited time the NOAA WP-3D was sampling over the sea-ice (Brock et al., 2010).

Although many of the open leads during ARCPAC were observed to be at least partially covered with thin ice, the leads were still a major moisture source to the ABL and resulting diamond dust may have played a role in the removal of $\mathrm{BC}$ particles through impaction scavenging by these ice crystals (Feng, 2009). A wet removal process whereby $\mathrm{BC}$ particles act as ice nuclei is less likely because clouds were generally not observed over the open leads. In general, very limited precipitation scavenging of total aerosol was observed during ARCPAC (Brock et al., 2010). This is in contrast to previous observations of preferential scavenging of $\mathrm{BC}$ as ice nuclei in mixed-phase clouds at a high-altitude site in midlatitudes (Cozic et al., 2008). Because it was difficult to unambiguously identify open-lead influenced air in the aircraft data, we cannot definitively comment on the potential role of open leads in the removal of $\mathrm{BC}$ with this dataset.

\subsection{Observational evidence for $\mathrm{BC}$ deposition}

As shown in Fig. 7, $\mathrm{BC}$ mass loadings and $\mathrm{CO}$ values were generally well correlated in the free troposphere for the 21 April flight. $\mathrm{BC}$ and $\mathrm{CO}$ were also correlated on 12 and 18 April when BC depletion occurred but we only show the data from 21 April because the dynamic range in $\mathrm{CO}$ is largest on this flight. The slope of the line through the main body of points (black) is $4.58 \pm 0.06 \mathrm{ng} \mathrm{BC}$ $(\mathrm{kg} \text { dry air })^{-1}(\mathrm{ppbCO})^{-1}$ and is representative of a mixture of biomass-burning influenced and aged Arctic air in the free troposphere. The data have been segregated by altitude to 


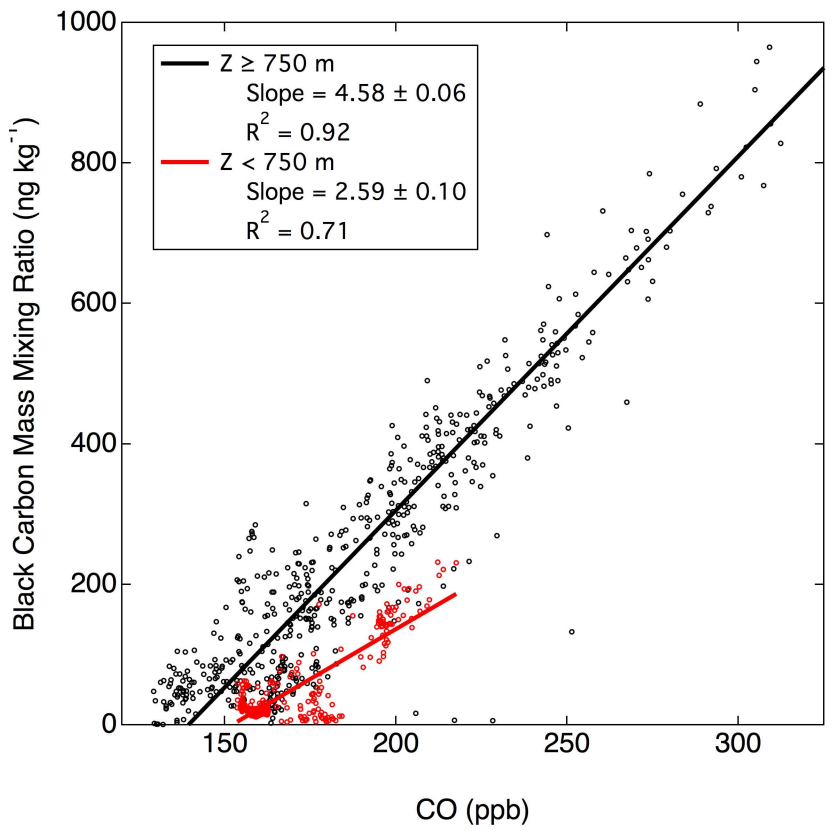

Fig. 7. Correlation between $\mathrm{BC}$ mass mixing ratio and $\mathrm{CO}$ mixing ratios for the flight of 21 April 2008. The $30 \mathrm{~s}$ data points are discriminated by altitude at $750 \mathrm{~m}$. The slope with one standard deviation and the $R^{2}$ value is shown for each linear regression.

highlight the data in the aged Arctic air over the sea-ice below $750 \mathrm{~m}$, the general altitude range for the observed $\mathrm{BC}$ vertical gradients as shown in Fig. 3. The correlation for the lower altitude data is different than for the free troposphere consistent with a process of $\mathrm{BC}$ removal in the ABL. The slope of this line (red), $2.59 \pm 0.10 \mathrm{ng} \mathrm{kg}^{-1} \mathrm{ppb}^{-1}$, mostly representative of the aged Arctic air, is less than that in the free troposphere. For a given value of $\mathrm{CO}$, the difference in $\mathrm{BC}$ mass between the regressions is greater than the maximum observed difference derived from the 21 April vertical profile in Fig. 3. This apparent discrepancy may be explained in part by a lower background $\mathrm{CO}$ in the biomass-burning layers aloft than in the aged Arctic air mass. The increasing $\mathrm{BC}$ mass differences between the regressions for increasing values of $\mathrm{CO}$, as demonstrated by the different slopes, may be related to the larger vertical gradients in $\mathrm{BC}$ mass observed on 21 April due to the biomass-burning plumes aloft compared to 12 April in the aged Arctic air mass. Further interpretation of the $\mathrm{BC}-\mathrm{CO}$ correlations requires a more detailed knowledge of the air parcel history.

The $\mathrm{O}_{3}-\mathrm{BC}$ correlation for all the flights and the entire sample altitude range is shown in Fig. 8a. Ozone is positively correlated with $\mathrm{BC}$ for the main body of points (i.e., $\mathrm{O}_{3}>40 \mathrm{ppb}, \mathrm{BC}>30 \mathrm{ng} \mathrm{kg}^{-1}$ ), associated with biomassburning plumes and anthropogenic pollution. Two other positive correlations are shown in Fig. 8b for the data in the ABL (red points) and across the boundary layer transition (blue points). Ozone mixing ratios and $\mathrm{BC}$ mass loadings are well correlated in ozone-depletion events (ODEs), account-

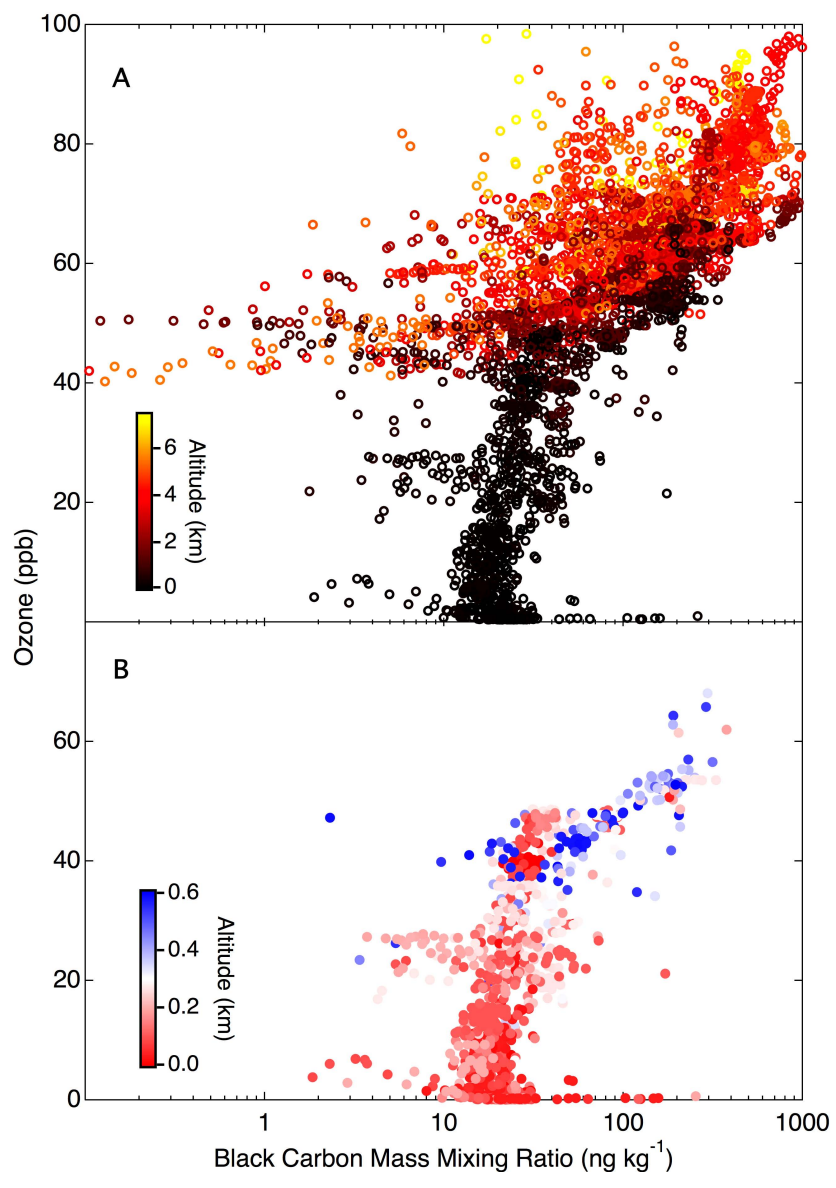

Fig. 8. Scatter plots of ozone and BC mass for 5 flights (12-21 April 2008) during ARCPAC for (A) the entire sample altitude range and (B) only up to $600 \mathrm{~m}$ altitude to explicitly show the different $\mathrm{O}_{3}$ - $\mathrm{BC}$ mixing lines in the $\mathrm{ABL}$ (red) and across the boundary layer transition (blue). The data points are $30 \mathrm{~s}$ averages and color-coded by altitude.

ing for most of the data in Fig. 8b. A different correlation with fewer data points (blue) is observed along a shallow mixing layer at the top of the ABL for $40<\mathrm{O}_{3}<55 \mathrm{ppb}$ and $30<\mathrm{BC}<200 \mathrm{ng} \mathrm{kg}^{-1}$, corresponding to a mixing line between the ozone-depleted air masses in the ABL and the pollution in the free troposphere. This mixing line corresponds to the largest $\mathrm{BC}$ vertical gradient which was usually observed between 300 and $750 \mathrm{~m}$ altitude. The maximum altitude shown in Fig. $8 \mathrm{~b}$ is $600 \mathrm{~m}$ because there is a lot of variability between 600 and $750 \mathrm{~m}$ altitude that obscures the correlations.

The $\mathrm{O}_{3}-\mathrm{BC}$ correlation in ODEs is robust over the course of 5 flights spanning 10 days with a total of $7 \mathrm{~h}$ sampling in the ABL. In the ODEs, $\mathrm{O}_{3}$ is removed through catalytic destruction by active bromine (Simpson et al., 2007). Enhancements of molecular bromine were observed in the ODEs during ARCPAC (Neuman et al., 2010). Molecular bromine is believed to be released to the atmosphere from 
brine during sea-ice formation and then rapidly photolyzed to active bromine. The ODEs effectively apply a stamp to an air mass that comes into contact with the sea-ice surface and the $\mathrm{O}_{3}$ mixing ratio in an air parcel is related to how much that air parcel mixed with air that interacted with the surface. As shown in Fig. 8b, lower $\mathrm{O}_{3}$ was generally found at lower altitude in the ABL and higher $\mathrm{O}_{3}$ near the top of the ABL consistent with a mixing process where the ozone destruction is greatest near the surface. With this line of reasoning, the correlation between $\mathrm{O}_{3}$ and $\mathrm{BC}$ mass in ODEs suggests that $\mathrm{BC}$ particles have been preferentially removed by a surface process such as dry deposition.

The competing hypothesis of precipitation scavenging of $\mathrm{BC}$ mass does not explain the positive $\mathrm{O}_{3}-\mathrm{BC}$ correlation in the ABL because it is expected that $\mathrm{BC}$-containing particles would be scavenged throughout the depth of the ABL or preferentially at the top of the ABL where clouds form in the vicinity of open leads in the sea-ice. Another possible hypothesis is that sedimentation of BC-containing particles, enhanced in size by hygroscopic materials in the ABL, could contribute to the deposition of the $\mathrm{BC}$ mass to the snow. However, the SP2 sizing information for the internally mixed $\mathrm{BC}$ particles sampled in the ABL suggests there is insignificant mass at the larger sizes required (approaching $1 \mu \mathrm{m}$ ) for sedimentation to make a significant contribution to $\mathrm{BC}$ removal.

\subsection{BC deposition flux}

We now place the observations in the context of what is expected from mixing processes in the springtime ABL. The first two profiles in the schematic in Fig. 9 are idealized cases assuming $\mathrm{BC}$ is predominantly removed by dry deposition. In the first case, rapid $\mathrm{ABL}$ mixing delivers $\mathrm{BC}$ to the snow surface where removal occurs faster than BC can be imported from the free troposphere. This results in a step-wise decrease in BC mass at the top of the ABL. In the second case, diffusion timescales are comparable across the boundary layer transition and in the ABL leading to a steadily decreasing $\mathrm{BC}$ mass with decreasing altitude through the $\mathrm{ABL}$ controlled by removal through contact with the surface. The third profile in the schematic qualitatively represents what was observed on multiple profiles in the ABL on 12,18, and 21 April. The largest BC gradient was generally observed in a shallow layer near the top of the ABL corresponding to the mixing line between $\mathrm{O}_{3}$ and $\mathrm{BC}$ in the tracer-tracer correlation in Fig. 8b. This BC gradient extends over a variable altitude range generally above $250 \mathrm{~m}$. A smaller positive vertical gradient was also observed in the ABL as depicted in Fig. 9. Although the measurements do not cleanly fit into either idealized case, they are more consistent with the profiles depicted by the fast ABL mixing case.

A simple box model is developed to estimate the deposition flux of $\mathrm{BC}$ aerosol to the snow. Fig. 10 shows a schematic of this 4-box system. A system of coupled linear differential equations is formulated to quantify the flux of $\mathrm{BC}$ from the free troposphere into the $\mathrm{ABL}$ and removal by contact with the surface:

$$
\begin{aligned}
& \frac{d C_{4}}{d t}=0 \\
& \frac{d C_{3}}{d t}=k_{\mathrm{FT}}\left(C_{4}-C_{3}\right)-k_{\mathrm{BL}}\left(C_{3}-C_{2}\right) \\
& \frac{d C_{2}}{d t}=k_{\mathrm{BL}}\left(C_{3}-C_{2}\right)-k_{\mathrm{BL}}\left(C_{2}-C_{1}\right) \\
& \frac{d C_{1}}{d t}=k_{\mathrm{BL}}\left(C_{2}-C_{1}\right)-f k_{\mathrm{BL}} C_{1}
\end{aligned}
$$

The BC mass loading in the aged Arctic air mass in the free troposphere is represented by $C_{4}$. The $\mathrm{BC}$ mass loadings in the $\mathrm{ABL}$ are partitioned into 3 boxes each representing $100 \mathrm{~m}$ altitude depth and given by $C_{3}, C_{2}$, and $C_{1}$. The free troposphere-to-boundary layer exchange coefficient, $k_{\mathrm{FT}}$, is inversely proportional to the e-folding timescale for mixing between the free troposphere and boundary layer. Similarly, the $\mathrm{ABL}$ exchange coefficient, $k_{\mathrm{BL}}$, is inversely proportional to the e-folding timescale for mixing between 2 adjacent boxes in the $\mathrm{ABL}$ and is considered constant throughout the depth of the boundary layer. The e-folding timescale for mixing through the full depth of the $\mathrm{ABL}$ is then expressed as $3 k_{\mathrm{BL}}^{-1}$. A removal efficiency factor, $f$, of $\mathrm{BC}$ particles is used in the model to scale the deposition velocity of $\mathrm{BC}$ mass from the lowest altitude box to the snow. The removal efficiency is an effective removal efficiency that represents the fraction of particles that actually come into direct contact with the surface and are removed. The removal efficiency factor is constrained by the observations.

This 4-box construct is the simplest system to model the flux of BC mass from the free troposphere into the ABL and to the surface. The 3 boxes in the ABL are sufficient to represent the $\mathrm{BC}$ vertical gradient in the $\mathrm{ABL}$ while more boxes do not add much additional value to the model results. The variables $k_{\mathrm{FT}}, k_{\mathrm{BL}}$, and $f$ are interrelated and not fully independent in the model. For example, the exchange coefficient $k_{\mathrm{FT}}$ is expressed as a small fraction of $k_{\mathrm{BL}}$ (i.e., $k_{\mathrm{FT}} / k_{\mathrm{BL}} \leq 0.15$ ) in the model because the observations indicate the diffusion timescale between the free troposphere and $\mathrm{ABL}$ is longer than that in the $\mathrm{ABL}$. This ratio controls the $\mathrm{BC}$ vertical gradient at the boundary layer transition at $\sim 300 \mathrm{~m}$ altitude as illustrated schematically in Fig. 9. Larger values of $f$ add a greater sink at the surface in the model driving the profile to smaller BC values as shown in the second panel of Fig. 9. We later prescribe a value for $k_{\mathrm{BL}}$ to estimate the deposition flux of $\mathrm{BC}$ mass to the snow surface. The choice of $k_{\mathrm{BL}}$ does not affect the steady-state concentrations of $\mathrm{BC}$ mass in $C_{4}-C_{1}$ but does affect how quickly the model distributes BC.

In theory, the system of Eqs. (1)-(4) can be solved uniquely for $k_{\mathrm{FT}} / k_{\mathrm{BL}}$ and $f$. However, the variability in the $\mathrm{BC}$ vertical profiles and the limited data at the boundary 

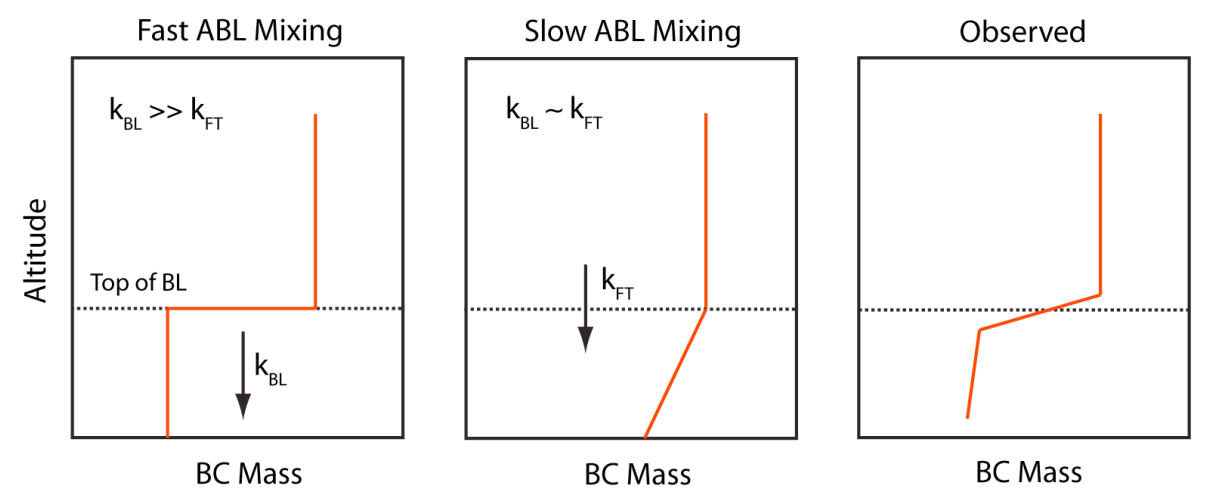

Fig. 9. Idealized and observed profiles in the springtime ABL. The first two profiles are idealized cases assuming BC mass is predominantly removed by dry deposition. The exchange coefficients $k_{\mathrm{BL}}$ and $k_{\mathrm{FT}}$ are inverses of the e-folding diffusion timescales for the ABL and the transition between the free troposphere and the ABL, respectively. In the first case, the boundary layer mixing is faster than mixing between the free troposphere and boundary layer. In the second case, the timescales for mixing from the free troposphere into the boundary layer are comparable to those in the boundary layer. The third panel generalizes the low-altitude BC profiles observed during ARCPAC.

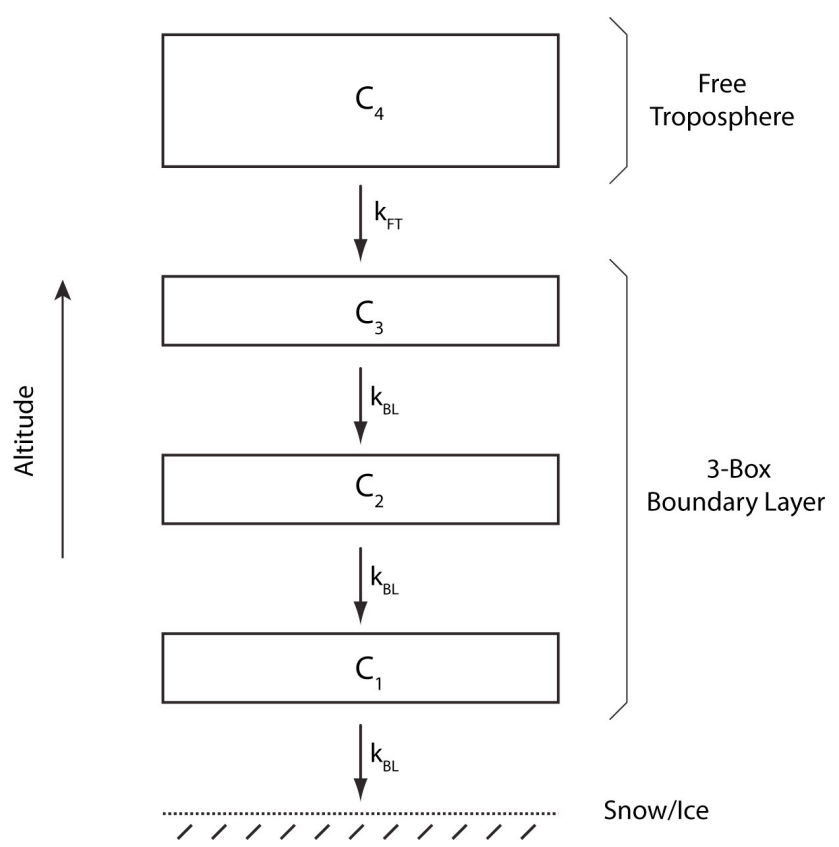

Fig. 10. Conceptual framework for a box model developed to examine the timescales for mixing of $\mathrm{BC}$ mass from the free troposphere into the $\mathrm{ABL}$ and to the snow surface. The $\mathrm{BC}$ mass loadings in the free troposphere and ABL are represented by $C_{4}$ and $C_{3}, C_{2}$, and $C_{1}$ respectively. The exchange coefficients $k_{\mathrm{FT}}$ and $k_{\mathrm{BL}}$ are the same as defined in the Fig. 9 caption.

layer transition ( $\sim 300$ to $750 \mathrm{~m}$ ) do not provide the tight constraints necessary to uniquely determine $k_{\mathrm{FT}} / k_{\mathrm{BL}}$ and $f$. Thus, a range of solutions bounding the observations with various values of $k_{\mathrm{FT}} / k_{\mathrm{BL}}$ and $f$ is shown in Fig. 11. These solutions are determined for the mean profile shown here but may not generally apply to BC depletion events in the ABL, such as the profile in Fig. 6c. The panels in Fig. 11 show the sensitivity of the model to the values of $k_{\mathrm{FT}} / k_{\mathrm{BL}}$ and $f$. As shown by the solid red and blue lines, the model better reproduces the $\mathrm{BC}$ vertical profiles in the $\mathrm{ABL}$ for $k_{\mathrm{FT}} / k_{\mathrm{BL}}$ values between 0.15 and 0.02 . This range of smaller values of $k_{\mathrm{FT}} / k_{\mathrm{BL}}$ confines more of the $\mathrm{BC}$ vertical gradient to the boundary layer transition. These solutions are consistent with the change in $\mathrm{BC}$ mass along the $\mathrm{O}_{3}-\mathrm{BC}$ mixing line at the boundary layer transition shown in Fig. 8b. To maintain the observed BC mass mixing ratios at the lowest altitudes in the profiles shown in Fig. 11, 1.5 to $10 \%$ removal efficiency is required for the $k_{\mathrm{FT}} / k_{\mathrm{BL}}$ values of 0.02 to 0.15 , respectively. In general, a larger inflection point grows into the profiles in Fig. 11 at $250 \mathrm{~m}$ altitude as both $k_{\mathrm{FT}} / k_{\mathrm{BL}}$ and $f$ decrease.

The box model results are used to estimate a dry deposition flux of $\mathrm{BC}$ aerosol to the surface. The most significant quantities in the flux calculation are the diffusion timescale at the boundary layer transition, given by $k_{\mathrm{FT}}^{-1}$, and the removal efficiency, $f$. The boundary layer mixing timescale, $3 k_{\mathrm{BL}}^{-1}$, is not included explicitly in the flux calculation because it is small relative to $k_{\mathrm{FT}}^{-1}$ and the flux calculation is only approximate given the limited observational constraints on the model solutions. The flux is calculated with the expression formulated here:

Dry Deposition Flux of $\mathrm{BC}=\frac{\Delta \mathrm{BC} \cdot f[1-(1 / e)] \cdot H}{k_{\mathrm{FT}}^{-1}}$

The total BC removal in units of $\mathrm{ng} \mathrm{kg}^{-1}$ for the e-folding diffusion timescale, $k_{\mathrm{FT}}^{-1}$, over the depth $H$ (corresponding to the depth of the $\mathrm{ABL}$ for the case here) is given by the expression, $\Delta \mathrm{BC} \cdot f[1-(1 / e)]$. The $\mathrm{BC}$ depletion, $\triangle \mathrm{BC}$, is estimated at $20 \mathrm{ng} \mathrm{kg}^{-1}$ over the $300 \mathrm{~m}$ depth of the ABL based on the underlying data (gray points) in Fig. 11 and described in detail in Sect. 3.2. 


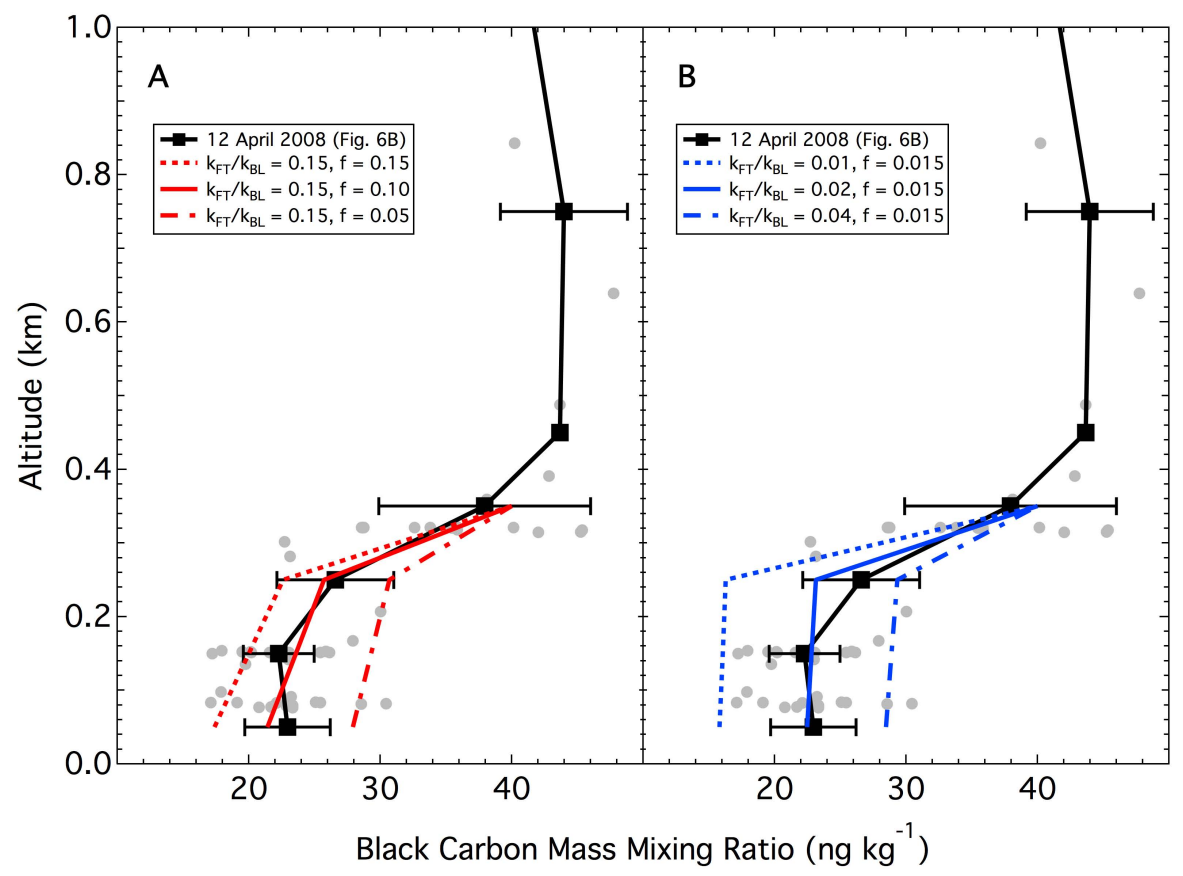

Fig. 11. Observed (black lines) and simulated (red and blue lines) vertical profiles of BC mass for measurements from 12 April 2008 (mean profile from Fig. 6B). The $30 \mathrm{~s} \mathrm{BC}$ data (gray points) are binned by altitude at $100 \mathrm{~m}$ resolution below and at $500 \mathrm{~m}$ resolution above $500 \mathrm{~m}$ altitude. The error bars are one standard deviation around the mean in each bin. The removal efficiency factor, $f$, is varied for a constant exchange coefficient ratio in (A) and vice versa in (B). The solutions denoted by the solid red and blue lines are used to estimate the deposition flux of BC mass to the surface.

Diffusion timescales as long as $8 \mathrm{~h}$ have been found at the South Pole for very stable, shallow boundary layers (Neff et al., 2008). However, the timescale could be much shorter under higher wind conditions with the potential for solar heating at the surface in the springtime Arctic. If we assume the boundary layer mixing timescale is $1 \mathrm{~h}$, then the model solutions indicate the diffusion timescales at the boundary layer transition, denoted by $k_{\mathrm{FT}}^{-1}$, are 2.2 to $17 \mathrm{~h}$ for the cases $k_{\mathrm{FT}} / k_{\mathrm{BL}}=0.15$ and 0.02 , respectively. The corresponding dry deposition fluxes then span a range between 5300 and $100 \mathrm{ng}\left(\mathrm{m}^{2} \text { day }\right)^{-1}$, respectively. If there had been more sampling at the boundary layer transition where the $\mathrm{BC}$ vertical gradient was the largest, it might have been possible to more tightly constrain the profiles in the box model and reduce this large range in deposition fluxes.

These flux estimates decrease for longer boundary layer turnover timescales in accordance with Eq. (5). A tracertracer correlation of $\mathrm{O}_{3}$ and $\mathrm{CO}$ (not shown) indicates the biomass-burning plumes in the free troposphere on 15-21 April generally did not mix into the ABL, except the synoptic-scale event on 19 April mentioned earlier, suggesting even longer free troposphere-to-boundary layer diffusion timescales than given by the box model results for an $\mathrm{ABL}$ diffusion timescale of $1 \mathrm{~h}$. A possible reason for this discrepancy may be that the physical mixing processes are less likely continuous as modeled but more likely episodic as the temperature difference between the air over the sea-ice and open leads enhances the mixing. During the ARCPAC sampling period, the WP-3D aircraft may not have sampled these episodic exchange processes despite flight legs over and near open leads.

Finally, these model-derived deposition fluxes are related to the measured BC mass in snow. When deposition occurs, we assume the snow exposed to the air is relatively uncompacted with a density of $100 \mathrm{~kg} \mathrm{~m}^{-3}$ based on a 10:1 snowto-liquid density ratio (Roebber et al., 2003). The climate data (1971-2000) at Barrow, Alaska, are probably representative of weather conditions over the Arctic Ocean in the general region where the aircraft measurements took place. The April mean temperature in Barrow of $-18^{\circ} \mathrm{C}$ may justify selecting a higher snow-to-liquid ratio but since the snow may be compacted somewhat upon initial impact with the surface, the 10:1 ratio is still used for this calculation. We then use the climatological April mean snowfall of $5.3 \mathrm{~cm}$ at Barrow to calculate the average $\mathrm{BC}$ mass in the snow based on the dry deposition fluxes from the box model. This equates to 0.6 to $30 \mathrm{ng} \mathrm{BC} \mathrm{(g} \mathrm{snow})^{-1}$ for a $1 \mathrm{~h} \mathrm{ABL}$ diffusion timescale. These derived values are plausible with respect to recent published results of 4 to $16 \mathrm{ng} \mathrm{g}^{-1}$ at the North Pole and in the North American Arctic, respectively (Hegg et al., $2009,2010)$. A contribution of $B C$ aerosol to the snow from precipitation scavenging would increase the values derived here for dry removal but, given the limited precipitation in the Arctic in the winter and spring, the total values would 
likely still be consistent with the large range of literature values for BC in snow across the Arctic (Flanner et al., 2007). The large range of reported $\mathrm{BC}$ loadings in snow may be partly explained by the interannual and seasonal variability in the amount of snowfall at a given site. The variability may also be affected by the interannual variability in BC mass advected to the Arctic and to what extent it is then mixed into the ABL and deposited to the snow surface.

\section{Summary}

Single-particle measurements of BC mass loadings from the NOAA WP-3D research aircraft were acquired from the ground to about $7 \mathrm{~km}$ in the springtime Arctic showing an increase of $\mathrm{BC}$ mass with increasing altitude from the $\mathrm{ABL}$ to the middle and upper troposphere. These $\mathrm{BC}$ aerosol measurements in the Arctic provide important constraints on global aerosol models. In the lowest $750 \mathrm{~m}$ over the sea-ice, a positive vertical gradient in BC mass was observed in many of the profiles. Sampling over the sea-ice generally occurred in the vicinity of open leads. The vertical gradient in BC mass was attributed to removal based on the $\mathrm{CO}$ data and $\mathrm{BC}$ size distributions that indicated air masses in the $\mathrm{ABL}$ and free troposphere had similar sources. BC mass and CO were well correlated throughout the free troposphere except the correlation changed in the ABL consistent with the $\mathrm{BC}$ depletions events. Ozone and BC were positively correlated in ODEs suggesting that $\mathrm{BC}$ mass was removed through dry deposition. Using a box model constrained by the $\mathrm{BC}$ measurements from the 12 April flight prior to the advection of biomass-burning plumes to the Arctic, we estimated a deposition flux of BC mass between 100 and $5300 \mathrm{ng}\left(\mathrm{m}^{2} \text { day }\right)^{-1}$ for a boundary layer e-folding diffusion timescale of $1 \mathrm{~h}$. These results were consistent with measurements of $\mathrm{BC}$ in snow based on the April climatology for Barrow.

Interannual variability in $\mathrm{BC}$ mass advected to the Arctic may affect the amount of $\mathrm{BC}$ deposited to the snow. However, the fate of $\mathrm{BC}$ aerosol ultimately depends on whether it is mixed from the free troposphere into the boundary layer before it is transported out of the Arctic. The analysis in this work indicates dry deposition of $\mathrm{BC}$ aerosol occurred in the aged Arctic air mass. There is no evidence that the biomass-burning layers in the free troposphere mixed into the ABL and reached the snow surface during the ARCPAC observation period. However, the work of Hegg et al. (2009) presents a conundrum because it suggests that the bulk of the $\mathrm{BC}$ in Arctic snow is attributed to fire sources. The spatially and temporally limited representativeness of the observations during ARCPAC may explain some of this disparity. On the other hand, the possible role of open leads in the sea-ice in facilitating the entrainment of biomass-burning layers aloft may also help to explain this discrepancy. Enhanced deposition may be occurring in regions influenced by open leads in the ice because the open leads facilitate mixing between the free troposphere and ABL under certain meteorological conditions. Additional observations will be important to evaluating this hypothesis and better understanding the processes controlling $\mathrm{BC}$ aerosol in the ABL that have important implications for Arctic climate.

Acknowledgements. We are grateful to K. D. Froyd and S. Lance for PALMS and cloud probe data, respectively, used to exclude cloud sampling from the black carbon data. We also thank J. Cozic for particle number concentration data supporting this analysis. This research was supported by the NOAA Atmospheric Composition and Climate Program, the NASA Radiation Sciences Program, and the NASA Upper Atmosphere Research Program.

Edited by: A. Stohl

\section{References}

Anderson, P. S. and Neff, W. D.: Boundary layer physics over snow and ice, Atmos. Chem. Phys., 8, 3563-3582, doi:10.5194/acp-83563-2008, 2008.

Andreas, E. L. and Murphy, B.: Bulk transfer coefficients for heat momentum over leads and polynyas, J. Phys. Ocean., 16, 18751883, 1986.

Brock, C. A., Hudson, P. K., Lovejoy, E. R., Sullivan, A., Nowak, J. B., Huey, L. G., Cooper, O. R., Cziczo, D. J., de Gouw, J., Fehsenfeld, F. C., Holloway, J. S., Hübler, G., Lafleur, B. G., Murphy, D. M., Neuman, J. A., Nicks, D. K., Orsini, D. A., Parrish, D. D., Ryerson, T. B., Tanner, D. J., Warneke, C., Weber, R. J., and Wilson, J. C.: Particle characteristics following cloud-modified transport from Asia to North America, J. Geophys. Res., 109, D23S26, doi:10.1029/2003JD004198, 2004.

Brock, C. A., Cozic, J., Bahreini, R., Froyd, K. D., Middlebrook, A. M., McComiskey, A., Brioude, J., Cooper, O. R., Stohl, A., Aikin, K. C., de Gouw, J. A., Fahey, D. W., Ferrare, R. A., Gao, R.-S., Gore, W., Holloway, J. S., Hübler, G., Jefferson, A., Lack, D. A., Lance, S., Moore, R. H., Murphy, D. M., Nenes, A., Novelli, P. C., Nowak, J. B., Ogren, J. A., Peischl, J., Pierce, R. B., Pilewskie, P., Quinn, P. K., Ryerson, T. B., Schmidt, K. S., Schwarz, J. P., Sodemann, H., Spackman, J. R., Stark, H., Thomson, D. S., Thornberry, T., Veres, P., Watts, L. A., Warneke, C., and Wollny, A. G., Characteristics, sources, and transport of aerosols measured in spring 2008 during the Aerosol, Radiation, and Cloud Processes Affecting Arctic Climate (ARCPAC) project, Atmos. Chem. Phys. Discuss., in preparation, 2010.

Cozic, J., Mertes, S., Verheggen, B., Cziczo, D. J., Gallavardin, S. J., Walter, S., Baltensperger, U., and Weingartner, E.: Black carbon enrichment in atmospheric ice particle residuals observed in lower tropospheric mixed phase clouds, J. Geophys. Res., 113, D15209, doi:10.1029/2007JD009266, 2008.

Doherty, S. J., Warren, S. G., Grenfell, T. C., Clarke, A. D., and Brandt, R. E.: Light-absorbing impurities in Arctic snow, Atmos. Chem. Phys. Discuss., 10, 18807-18878, doi:10.5194/acpd-1018807-2010, 2010.

Feng, J.: A size-resolved model for below-cloud scavenging of aerosols by snowfall, J. Geophys. Res., 114, D08203, doi:10.1029/2008JD011012, 2009.

Flanner, M. G., Zender, C. S., Randerson, J. T., and Rasch, P. J.: Present-day climate forcing and response from 
black carbon in snow: J. Geophys. Res., 112, D11202, doi:10.1029/2006JD008003, 2007.

Flanner, M. G., Zender, C. S., Hess, P. G., Mahowald, N. M., Painter, T. H., Ramanathan, V., and Rasch, P. J.: Springtime warming and reduced snow cover from carbonaceous particles, Atmos. Chem. Phys., 9, 2481-2497, doi:10.5194/acp-9-24812009, 2009.

Froyd, K. D., Murphy, D. M., Lawson, P., Baumgardner, D., and Herman, R. L.: Aerosols that form subvisible cirrus at the tropical tropopause, Atmos. Chem. Phys., 10, 209-218, doi:10.5194/acp-10-209-2010, 2010.

Fuelberg, H. E., Harrigan, D. L., and Sessions, W.: A meteorological overview of the ARCTAS 2008 mission, Atmos. Chem. Phys., 10, 817-842, doi:10.5194/acp-10-817-2010, 2010.

Generoso, S., Bey, I., Attié, J.-L., and Bréon, F.-M.: A satelliteand model-based assessment of the 2003 Russian fires: Impact on the Arctic region, J. Geophys. Res., 112, D15302, doi:10.1029/2006JD008344, 2007.

Hansen, A. D. A. and Novakov, T.: Aerosol black carbon measurements in the Arctic haze during AGASP-II, J. Atmos. Chem., 9, 347-361, 1989.

Hansen, A. D. A. and Rosen, H.: Vertical distributions of particulate carbon, sulfur, and bromine in the Arctic haze and comparison with ground-level measurements at Barrow, Alaska, Geophys. Res. Lett., 11(5), 381-384, 1984.

Hansen, J. and Nazarenko, L.: Soot climate forcing via snow and ice albedos, P. Natl. Acad. Sci., 101, 423-428, 2004.

Hegg, D. A., Warren, S. G., Grenfell, T. C., Doherty, S. J., and Clarke, A. D.: Sources of light-absorbing aerosol in arctic snow and their seasonal variation, Atmos. Chem. Phys. Discuss., 10, 13755-13796, doi:10.5194/acpd-10-13755-2010, 2010.

Hegg, D. A., Warren, S. G., Grenfell, T. C., Doherty, S. J., Larson, T. V., and Clarke, A. D.: Source attribution of black carbon in Arctic snow, Environ. Sci. Technol., 43(11), 4016-4021, doi:10.1021/es803623f, 2009.

Holloway, J. S., Jakoubek, R. O., Parrish, D. D., Gerbig, C., VolzThomas, A., Schmitgen, S., Fried, A., Wert, B., Henry, B., and Drummond, J. R.: Airborne intercomparison of vacuum ultraviolet fluorescence and tunable diode laser absorption measurements of tropospheric carbon monoxide, J. Geophys. Res., 105, 24251-24261, 2000.

IPCC: Climate Change 2007: The Physical Science Basis, Contribution of Working Group I to the Fourth Assessment Report of the Intergovernmental Panel on Climate Change, edited by: Solomon, S., Qin, D., Manning, M., Chen, Z., Marquis, M., Averyt, K. B., Tignor, M., and Miller, H. L., Cambridge University Press, Cambridge, UK and New York, NY, USA, 996 pp., 2007.

Jacob, D. J., Crawford, J. H., Maring, H., Clarke, A. D., Dibb, J. E., Emmons, L. K., Ferrare, R. A., Hostetler, C. A., Russell, P. B., Singh, H. B., Thompson, A. M., Shaw, G. E., McCauley, E., Pederson, J. R., and Fisher, J. A.: The Arctic Research of the Composition of the Troposphere from Aircraft and Satellites (ARCTAS) mission: design, execution, and first results, Atmos. Chem. Phys., 10, 5191-5212, doi:10.5194/acp-10-5191-2010, 2010.

Jacobson, M.: Strong radiative heating due to the mixing state of black carbon in atmospheric aerosols, Nature, 409, 695-697, 2001.

Koch, D. and Hansen, J.: Distant origins of Arctic black carbon: A Goddard Institute for Space Studies ModelE experiment, J.
Geophys. Res., 110, D04204, doi:10.1029/2004JD005296, 2005. Koch, D., Schulz, M., Kinne, S., McNaughton, C., Spackman, J. R., Balkanski, Y., Bauer, S., Berntsen, T., Bond, T. C., Boucher, O., Chin, M., Clarke, A., De Luca, N., Dentener, F., Diehl, T., Dubovik, O., Easter, R., Fahey, D. W., Feichter, J., Fillmore, D., Freitag, S., Ghan, S., Ginoux, P., Gong, S., Horowitz, L., Iversen, T., Kirkevåg, A., Klimont, Z., Kondo, Y., Krol, M., Liu, X., Miller, R., Montanaro, V., Moteki, N., Myhre, G., Penner, J. E., Perlwitz, J., Pitari, G., Reddy, S., Sahu, L., Sakamoto, H., Schuster, G., Schwarz, J. P., Seland, Ø., Stier, P., Takegawa, N., Takemura, T., Textor, C., van Aardenne, J. A., and Zhao, Y.: Evaluation of black carbon estimations in global aerosol models, Atmos. Chem. Phys., 9, 9001-9026, doi:10.5194/acp-9-9001-2009, 2009.

Law, K. S. and Stohl, A.: Arctic air pollution: Origins and impacts, Science, 315, 1537-1540, 2007.

McConnell, J. R., Edwards, R., Kok, G. L., Flanner, M. G., Zender, C. S., Saltzman, E. S., Banta, J. R., Pasteris, D. R., Carter, M M., and Kahl, J. D. W.: 20th-Century industrial black carbon emissions altered Arctic climate forcing, Science, 317, 13811384, 2007.

McNaughton, C. M., Clarke, A. D., Freitag, S., Kapustin, V. N., Kondo, Y., Moteki, N., Sahu, L., Takegawa, N., Fahey, D. W., Gao, R. S., Schwarz, J. P., Spackman, J. R., Watts, L., Diskin, G., Podolske, J., Holloway, J. S., Wisthaler, A., Mikoviny, T., de Gouw, J., Warneke, C., Jimenez, J., Cubison, M., Howell, S. G., Middlebrook, A. M., Bahreini, R., Anderson, B. E., Winstead, E., Thornhill, K. L., Lack, D., Cozic, J., and Brock, C. A.: Absorbing aerosol in the troposphere of the Western Arctic during the 2008 ARCTAS/ARCPAC airborne field campaigns, Atmos. Phys. Chem. Discuss., in preparation, 2010.

Neff, W. D., Helmig, D., Grachev, A., and Davis, D.: A study of boundary layer behavior associated with high NO concentrations at the South Pole using minisodar, tethered balloon, and sonic anemometer, Atmos. Environ., 42, 2762-2779, doi:10.1016/j.atmosenv.2007.01.033, 2008.

Neuman, J. A., Nowak, J. B., Huey, L. G., Burkholder, J. B., Dibb, J. E., Holloway, J. S., Liao, J., Peischl, J., Roberts, J. M., Ryerson, T. B., Scheuer, E., Stark, H., Stickel, R. E., Tanner, D. J., and Weinheimer, A.: Bromine measurements in ozone depleted air over the Arctic Ocean, Atmos. Chem. Phys., 10, 6503-6514, doi:10.5194/acp-10-6503-2010, 2010.

Quinn, P. K., Shaw, G., Andrews, E., Dutton, E. G., Ruoho-Airola, T., and Gong, S. L.: Arctic haze: current trends and knowledge gaps, Tellus B, 59, 99-114, 2007.

Roebber, P. J., Bruening, S. L., Schultz, D. M., and Cortinas, J. V.: Improving snowfall forecasting by diagnosing snow density, Wea. Forecast., 18, 264-287, 2003.

Ryerson, T. B., Buhr, M. P., Frost, G. J., Goldan, P. D., Holloway, J. S., Hübler, G., Jobson, B. T., Kuster, W. C., McKeen, S. A., Parrish, D. D., Roberts, J. M., Sueper, D. T., Trainer, M. T., Williams, J., and Fehsenfeld, F. C.: Emissions lifetimes and ozone formation in power plant plumes, J. Geophys. Res., 103, 22569-22583, 1998.

Saha, A., O’Neill, N. T., Eloranta, E., Stone, R. S., Eck, T. F., Zidane, S., Daou, D., Lupu, A., Lesins, G., Shiobara, M., and McArthur, L. J. B.: Pan-Arctic sunphotometry during the ARCTAS-A campaign of April 2008, Geophys. Res. Lett., 37, L05803, doi:10.1029/2009GL041375, 2010. 
Schnell, R. C.: Arctic haze and the Arctic Gas and Aerosol Sampling Program (AGASP), Geophys. Res. Lett., 11, 361-364, 1984.

Schwarz, J. P., Gao, R. S., Fahey, D. W., Thomson, D. S., Watts, L. A., Wilson, J. C., Reeves, J. M., Darbeheshti, M., Baumgardner, D. G., Kok, G. L., Chung, S. H., Schulz, M., Hendricks, J., Lauer, A., Kärcher, B., Slowik, J. G., Rosenlof, K. H., Thompson, T. L., Langford, A. O., Loewenstein, M., and Aikin, K. C.: Single-particle measurements of midlatitude black carbon and light-scattering aerosols from the boundary layer to the lower stratosphere, J. Geophys. Res., 111, D16207, doi:10.1029/2006JD007076, 2006.

Schwarz, J. P., Spackman, J. R., Fahey, D. W., Gao, R. S., Lohmann, U., Stier, P., Watts, L. A., Thomson, D. S., Lack, D. A., Pfister, L., Mahoney, M. J., Baumgardner, D., Wilson, J. C., and Reeves, J. M.: Coatings and their enhancement of black carbon light absorption in the tropical atmosphere, J. Geophys. Res., 113, D03203, doi:10.1029/2007JD009042, 2008.

Serreze, M. C., Maslanik, J. A., Rehder, M. C., Schnell, R. C., Kahl, J. D., and Andreas, E. L.: Theoretical heights of buoyant convection above open leads in the winter Arctic pack ice cover, J. Geophys. Res., 97, 9411-9422, 1992.

Sharma, S., Andrews, E., Barrie, L. A., Ogren, J. A., and Lavoué, D.: Variations and sources of the equivalent black carbon in the high Arctic revealed by long-term observations at Alert and Barrow: 1989-2003, J. Geophys. Res., 111, D14208, doi:10.1029/2005JD006581, 2006.

Shindell, D. T., Chin, M., Dentener, F., Doherty, R. M., Faluvegi, G., Fiore, A. M., Hess, P., Koch, D. M., MacKenzie, I. A., Sanderson, M. G., Schultz, M. G., Schulz, M., Stevenson, D. S., Teich, H., Textor, C., Wild, O., Bergmann, D. J., Bey, I., Bian, H., Cuvelier, C., Duncan, B. N., Folberth, G., Horowitz, L. W., Jonson, J., Kaminski, J. W., Marmer, E., Park, R., Pringle, K. J., Schroeder, S., Szopa, S., Takemura, T., Zeng, G., Keating, T. J., and Zuber, A.: A multi-model assessment of pollution transport to the Arctic, Atmos. Chem. Phys., 8, 5353-5372, doi:10.5194/acp-8-5353-2008, 2008.

Shindell, D. and Faluvegi, G.: Climate response to regional radiative forcing during the twentieth century, Nat. Geosci., 2, 294 300, doi:10.1038/NGEO473, 2009.

Shiraiwa, M., Kondo, Y., Moteki, N., Takegawa, N., Miyazaki, Y., and Blake, D. R.: Evolution of mixing state of black carbon in polluted air from Tokyo, Geophys. Res. Lett., 34, L16803, doi:10.1029/2007GL029819, 2007.

Simpson, W. R., von Glasow, R., Riedel, K., Anderson, P., Ariya, P., Bottenheim, J., Burrows, J., Carpenter, L. J., Frieß, U., Goodsite, M. E., Heard, D., Hutterli, M., Jacobi, H.-W., Kaleschke, L., Neff, B., Plane, J., Platt, U., Richter, A., Roscoe, H., Sander, R., Shepson, P., Sodeau, J., Steffen, A., Wagner, T., and Wolff, E.: Halogens and their role in polar boundary-layer ozone depletion, Atmos. Chem. Phys., 7, 4375-4418, doi:10.5194/acp-74375-2007, 2007.
Slowik, J. G., Cross, E. S., Han, J.-H., Davidovits, P., Onasch, T. B., Jayne, J. T., Williams, L. R., Canagaratna, M. R., Worsnop, D. R., Chakrabarty, R. K., Moosmüller, H., Arnott, W. P., Schwarz, J. P., Gao, R.-S., Fahey, D. W., Kok, G. L., and Petzold, A.: An inter-comparison of instruments measuring black carbon content of soot particles, Aerosol Sci. Tech., 41, 295-314, 2007.

Spackman, J. R., Schwarz, J. P., Gao, R. S., Watts, L. A., Thomson, D. S., Fahey, D. W., Holloway, J. S., de Gouw, J. A., Trainer, M., and Ryerson, T. B.: Empirical correlations between black carbon aerosol and carbon monoxide in the lower and middle troposphere, Geophys. Res. Lett., 35, L19816, doi:10.1029/2008GL035237, 2008.

Stohl, A.: Characteristics of atmospheric transport in the Arctic troposphere, J. Geophys. Res., 111, D11306, doi:10.1029/2005JD006888, 2006.

Strunin, M. A., Postnov, A. A., and Mezrin, M. Y.: Meteorological potential for contamination of arctic troposphere: Boundary layer structure and turbulent diffusion characteristics, J. Atmos. Res., 44, 37-51, 1997.

Sturges, W. T.: Pollution of the Arctic Atmosphere, Elsevier Science Publishing, London, UK and New York, NY, USA, 334 pp., 1991.

Tjernström, M. and Graversen, R. G.: The vertical structure of the lower Arctic troposphere analysed from observations and the ERA-40 reanalysis, Q. J. Roy. Meteor. Soc., 135, 431-443, doi:10.1002/qj.380, 2009.

Warneke, C., Bahreini, R., Brioude, J., Brock, C. A., de Gouw, J. A., Fahey, D. W., Froyd, K. D., Holloway, J. S., Middlebrook, A., Miller, L., Montzka, S., Murphy, D. M., Peischl, J., Ryerson, T. B., Schwarz, J. P., Spackman, J. R., and Veres, P.: Biomass burning in Siberia and Kazakhstan as an important source for haze over the Alaskan Arctic in April 2008, Geophys. Res. Lett., 36, L02813, doi:10.1029/2008GL036194, 2009.

Warneke, C., Froyd, K. D., Brioude, J., Bahreini, R., Brock, C. A., Cozic, J., de Gouw, J. A., Fahey, D. W., Ferrare, R., Holloway, J. S., Middlebrook, A. M., Miller, L., Montzka, S., Schwarz, J. P., Sodemann, H., Spackman, J. R., and Stohl, A.: An important contribution to springtime Arctic aerosol from biomass-burning in Russia, Geophys. Res. Lett., 37, L01801, doi:10.1029/2009GL041816, 2010.

Wilson, J. C., Lafleur, B. G., Hilbert, H., Seebaugh, W. R., Fox, J., Gesler, D. W., Brock, C. A., Huebert, B. J., and Mullen, J.: Function and performance of a low turbulence inlet for sampling super-micron particles from aircraft platforms, Aerosol Sci. Tech., 38, 790-802, 2004. 